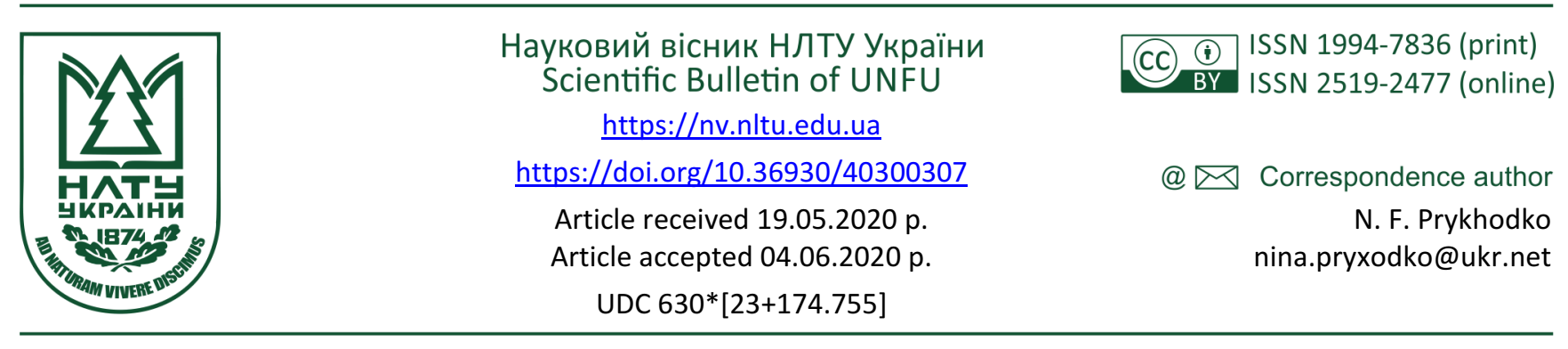

Н. Ф. Приходько1, Т. В. Парпан ${ }^{1}$, О. М. Ткачук', М. М. Приходько

${ }^{1}$ Український НДІ гірського лісівництва ім. П. С. Пастернака, м. Івано-Франківськ, Украӥна
${ }^{2}$ Івано-Франківський національний технічний університет нафти і газу, м. Івано-Франківськ, Украӥна

\title{
РАДІАЛЬНИЙ ПРИРІСТ ЯЛИНИ ЄВРОПЕЙСЬКОЇ (РІСЕА АВІЕS L.) В ОСЕРЕДКУ ЇЇ ВСИХАННЯ (ГОРГАНИ, УКРАЇНСЬКІ КАРПАТИ)
}

\begin{abstract}
Упродовж останніх років відбувається інтенсивне всихання ялинових лісів в Українських Карпатах. Цей процес завдає економічних збитків, призводить до погіршення життєвого стану ялинників та зниження рівня надання екосистемних послуг лісами. Для встановлення щорічного радіального приросту ялини європейської та його динаміки, а також подальшого обгрунтування лісівничих заходів у гірському масиві Горган у дуже ослаблому за санітарним станом та складним за структурою мішаному деревостані в 2019 р. здійснено дендрохронологічні дослідження. Виявлено стрімке зниження приросту ялини, починаючи із першого класу віку, яке може бути пов'язане (окрім інших факторів) із міжвидовою конкуренцією (ялини і ялиці). Середній приріст деревостану за досліджуваний період становить 1,97 мм/рік. Найменші радіальні прирости ялини (1,05 мм/рік) були в 1980-2000 рр., коли деревостан проходив стадію розладнання. За останні 20 років середній приріст дещо збільшився $(1,19$ мм/рік), очевидно, внаслідок розрідження деревостану. Коливання відносних індексів приростів знаходяться в межах 84,24-115,52\%. Середня тривалість циклів приростів 8 років. Починаючи iз середини XX ст., частота коливань приростів збільшилася, а отже, умови середовища стали екстремальнішими для росту ялини. Теперішній склад підросту свідчить про те, що в майбутньому на дослідному об'єкті відбудеться зміна біоценозу. Під час дендрохронологічних досліджень в осередках всихання ялини, необхідна різнобічна інформація про природні й антропогенні фактори, які можуть впливати на радіальний приріст дерев та його мінливість.
\end{abstract}

Ключові слова: індивідуальні деревно-кільцеві хронології; узагальнені деревно-кільцеві хронології; індекси радіального приросту; цикли радіального приросту.

\section{Вступ}

Площа всихання ялинових лісів у регіоні Українських Карпат станом на 2018 р. становить понад 36 тис. га, а маса всихаючої на корені деревини - понад 11 млн $\mathrm{m}^{3}$ [8]. Цей процес завдає економічних збитків, призводить до погіршення стану та продуктивності лісів у Карпатах, зниження рівня надання екосистемних послуг лісами, погіршення виконуваних ними функцій що відповідно призводить до небезпечних екзогенних процесів (повеней, паводків, ерозії, селей, зсувів) [5, 13].

Характерні зовнішні ознаки порушень життєдіяльності деревостанів і статистично достовірні зміни таксаційних показників з'являються тільки за руйнівного впливу природних і антропогенних факторів, коли, частіше за все, зміни в екосистемах уже незворотні. Вирішити проблему деградації і відмирання лісів неможливо, виходячи тільки із досліджень окремих процесів. Дослідження мають бути спрямовані на вивчення часо- вої динаміки мінливості продукційного процесу, відображеного в наростанні стовбурової маси під впливом природних і антропогенних факторів. У ролі індикатора, що дає змогу оцінити зміни в лісових екосистемах, $є$ річне кільце Радіальний приріст дерев (ширина річного кільця) знаходиться під контролем внутрішніх факторів і модифікується зовнішніми [7, 9, 16, 17].

Об'єкт дослідження - осередок всихання ялини європейської.

Предмет дослідження - методи і засоби визначення радіального приросту ялини європейської та його динаміка в осередку всихання, що дасть змогу проводити іiі дендрохронологічні дослідження, які можуть впливати на радіальний приріст дерев та його мінливість.

Мета дослідження - встановити величину та динаміку радіального приросту ялини європейської в осередку ії всихання для подальшого планування лісівничих заходів.

\section{Інформація про авторів:}

Приходько Ніна Филимонівна, наук. співробітник, лабораторія екології та захисту лісу. Email: nina.pryxodko@ukr.net; https://orcid.org/0000-0003-1393-207X

Парпан Тарас Васильович, канд. с.-г. наук, ст. наук. співробітник, лабораторія екології та захисту лісу. Email: tarasparpan@gmail.com; https://orcid.org/0000-0002-8459-0479

Ткачук Оксана Михайлівна, канд. с.-г. наук, в.о. завідувача лабораторії екології та захисту лісу. Email: tkachyk.oksana1988@gmail.com; https://orcid.org/0000-0002-7569-0523

Приходько Микола Миколайович, д-р геогр. наук, професор, кафедра геодезії та землеустрою. Email: prihodkon@ukr.net; https://orcid.org/0000-0003-0508-8702

Цитування за ДСтУ: Приходько Н. Ф., Парпан Т. В., Ткачук О. М., Приходько М. М. Радіальний приріст ялини європейської (Рісеа abies L.) в осередку її всихання (Горгани, Українські Карпати). Науковий вісник НлтУ України. 2020, т. 30, № 3. С. 41-46.

Citation APA: Prykhodko, N. F., Parpan, T. V., Tkachuk, O. M., \& Prykhodko, M. M. (2020). Radial growth of european spruce (Picea abies L.) in its drying out environment (Gorgany, the Ukrainian Carpathians). Scientific Bulletin of UNFU, 30(3), 41-46. https://doi.org/10.36930/40300307 
Завдання дослідження: визначити величину щорічних радіальних приростів модельних дерев ялини європейської в осередку всихання; дослідити динаміку, мінливість та цикли радіального приросту ялини.

Наукова новизна дослідження полягає у тому, що було вперше розроблено методику, яка дає змогу встановити кількісні показники радіального приросту ялини європейської в осередку ії всихання, амплітуди коливань та циклічності приростів, виявленні експресивних і депресивних періодів ії росту.

Практичне значення результатів дослідження полягає в тому, що їх можна використати для оцінювання динамічних процесів у лісовій екосистемі в осередку всихання ялини внаслідок впливу різних факторів, прогнозу радіального приросту ялини та планування лісівничих заходів.

Аналіз літературних джерел. Дендрохронологічні методи широко використовують під час вивчення історії лісових фітоценозів, для відтворення довгострокової динаміки та циклічності клімату [10], для вивчення стану та динаміки лісових екосистем та реконструкції факторів зовнішнього середовища за довгі інтервали часу з високою часовою роздільною здатністю [4], виявлення механізмів формування деревини в онтогенезі.

Регіональна синхронізація радіального приросту первинного лісу Picea abies вздовж Карпатської дуги показала часові коливання приросту впродовж всього XX ст. Приріст дерев, загалом, збільшується із підвищенням температури, і $є$ ознакою того, що ділянки гірських хребтів переходять від обмеження температури до обмеження вологості [14]. У Східних Карпатах обмежувальним фактором росту деревостанів ялини на всіх етапах сукцесії стає зимова посуха. Очікується, що частота і масштаби природних порушень, а також посухи збільшаться із змінами клімату [18]. Довготривалі зміни клімату істотно впливають на ріст дерев та поширення видів в Свропі [15].

Дендрохронологічні дослідження в Україні започаткував Ф.Н. Шведов [17] наприкінці ХІХ ст. Грунтовніше їх почали здійснювати у другій половині XX ст. [6, 7]. В Українських Карпатах дендрохронологічних досліджень виконано небагато [6]. Досліджень радіального приросту ялини європейської в осередках всихання в Карпатах ми не виявили.

Матеріали і методи дослідження. Дендрохронологічні дослідження здійснювали у 2019 р. в осередку всихання ялини на постійному дослідному об'єкті, закладеному в Долинському районі Івано-Франківської області в межах виконання бюджетної науково-дослідної роботи № 8 "Розробити прогноз санітарного стану та запропонувати комплекс заходів із використання всихаючих ялинників Карпат 3 врахуванням екологічних, економічних та соціальних підходів".

Дослідний об'єкт (географічні координати 4847'30.5" північної широти, 2343'53.7" східної довготи) розташований на території Людвиківського лісництва ДП "Вигодське лісове господарство" (Зовнішні Карпати, Горгани) (табл. 1). Це найбільш піднятий над рівнем моря гірський район, який простягнувся від Сколівських Бескид на північному заході до Покутських Карпат на південному сході. Північна частина території розчленована Вигодською котловиною, по якій протікає річка Свіча $з$ притокою Мізунькою.

Табл. 1. Характеристика постійного дослідного об'єкта

\begin{tabular}{|c|c|c|c|c|c|c|c|c|c|}
\hline $\begin{array}{l}\text { Державне підприємство, лісниц- } \\
\text { тво, квартал/виділ }\end{array}$ & $\begin{array}{c}\text { Тип лісу, склад } \\
\text { деревостану }\end{array}$ & \begin{tabular}{|c|} 
Висота \\
н.р.м., м \\
\end{tabular} & $\begin{array}{l}\text { Крутизна } \\
\text { схилу, град. }\end{array}$ & $\begin{array}{l}\text { Вік, } \\
\text { років }\end{array}$ & $\begin{array}{l}\text { Середній } \\
\text { діаметр, см }\end{array}$ & $\begin{array}{c}\text { Середня } \\
\text { висота, м }\end{array}$ & $\begin{array}{c}\text { Боні- } \\
\text { тет }\end{array}$ & $\begin{array}{c}\text { Повно- } \\
\text { та }\end{array}$ & $\begin{array}{c}\text { Запас, } \\
\text { м }^{3} / г \mathrm{a} \\
\end{array}$ \\
\hline $\begin{array}{l}\text { ДП "Вигодське лісове господар- } \\
\text { ство", Людвиківське л-во, 14/42 }\end{array}$ & $\begin{array}{c}\mathrm{C}_{3}-\text {-б-яЦ-См } \\
8 \text { ЯЛЕ2ЯЦБ+ЯВ }\end{array}$ & 800 & 40 & 118 & $\begin{array}{l}32 \text { м (ЯЛЕ), } \\
38 \text { м (ЯЦБ) }\end{array}$ & $\begin{array}{l}29 \text { м (ЯЛЕ), } \\
30 \text { м (ЯЦБ) }\end{array}$ & I & 0,66 & 723 \\
\hline
\end{tabular}

Переважна частина площі лісового господарства характеризується різко вираженим гірським рельєфом із схилами крутизною $20^{\circ}-30^{\circ}$, рідше $-40^{\circ}$ і більше. У лісовому фонді переважають хвойні насадження - 78,8 \%, зокрема ялинові - 72,8\%.

Клімат на досліджуваній території помірно-континентальний вологий, прохолодний влітку та м'який взимку. Випадає 760-1060 мм опадів за рік. Тривалість вегетаційного періоду 190-200 днів. Висота снігового покриву сягає 50 см. Низькі температури зимових місяців великої шкоди лісовому господарству не завдають. Відчутнішої шкоди завдають пізні весняні заморозки, які пошкоджують, а іноді призводять до повного відмирання сходів і молодих пагонів бука, ясеня, дуба, ялиці і деяких інших порід. В осінньо-зимовий період спостерігаються вітри, швидкість яких перевищує 15 м/с. Для цього району також характерні вітри великої сили - до 40 м/с, які супроводжуються вітровалами і вітроломами, переважно в ялинових насадженнях.

Візуально стан деревостану на дослідному об'єкті характеризується вираженими ознаками всихання (рис. 1). Детальні обстеження санітарного стану показали, що дерева ялини європейської на дослідному об'єкті дуже ослаблені. Виявлено 5 видів пошкоджень на 47 деревах із 132, а саме: дві верхівки (1 шт.), нахил (6 шт.), вигин (3 шт.), поперечний рак (1 шт.), пошко- дження короїдами (39 шт.). Пошкодження ялини короїдами наявне переважно у дерев 5 і 6 категорій стану (свіжий і старий сухостій). Стан ялини удвічі гірший, ніж ялиці.

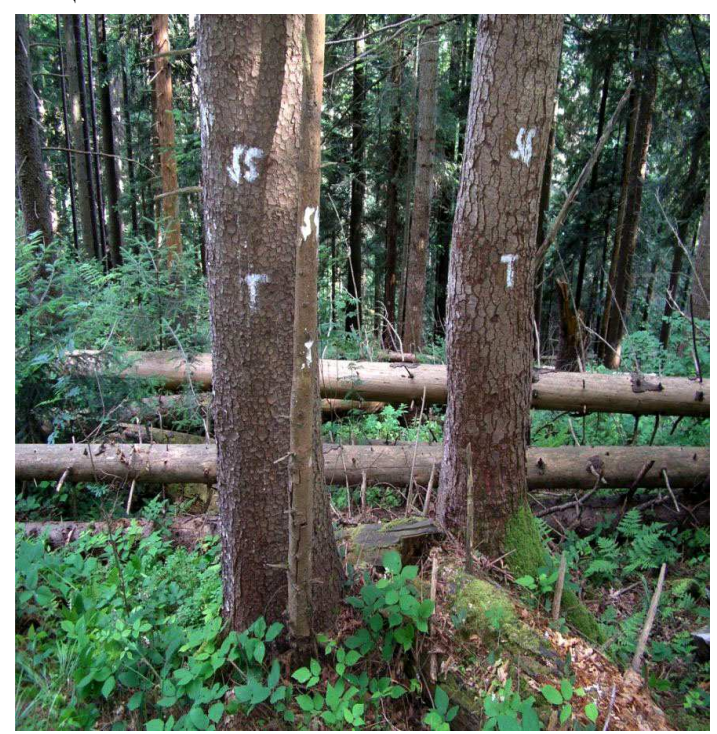

Рис. 1. Всихаючий деревостан ялини європейської на дослідному об'єкті

Поблизу дослідного об'єкта методом довільної вибірки вибирали візуально здорові дерева ялини євро- 
пейської з урахуванням ступінчастого (за діаметром) представництва, у яких віковим буравом Пресслера відбирали керни деревини (12 кернів) на висоті 1,3 м. Ширину річних кілець вимірювали на мікрометрі digi-met 3 точністю до 0,01 мм. За результатами вимірювань визначали щорічні радіальні прирости кожного модельного дерева, будували індивідуальні та узагальнену деревнокільцеві хронології.

Для унеможливлення впливу фактора віку на динаміку радіального приросту, проводили стандартизацію даних (розраховували відносні індекси приростів).

Стандартизацію даних виконували в два етапи. На першому етапі - розраховували "норми приросту". Для знаходження норми приросту застосовували метод ковзного згладжування 3 11-річним періодом усереднення. На другому етапі розраховували відносні індекси річних приростів за формулою: $I=$ iflis. $100 \%$, де $I$ - відносний індекс, \%; if - фактична ширина річного кільця, мм; is - згладжена ширина річного кільця (норма приросту даного року), мм.

\section{Результати дослідження}

На графіку кривих абсолютних щорічних радіальних приростів модельних дерев ялини європейської (рис. 2) видно, що дерева у перші 20 років мали найбільші, хоча і різні, прирости, які змінюються від 2,96 (дерево № 2, 1912 р.) до 8,89 мм (дерево № 11, 1925 р.), які з часом зменшилися, й у 1958 р. всі дерева мали приріст менше ніж 1,60 мм. Після 1958 р. деякі дерева збільшили приріст з певними флуктуаціями, проте більшість дерев зменшили приріст.

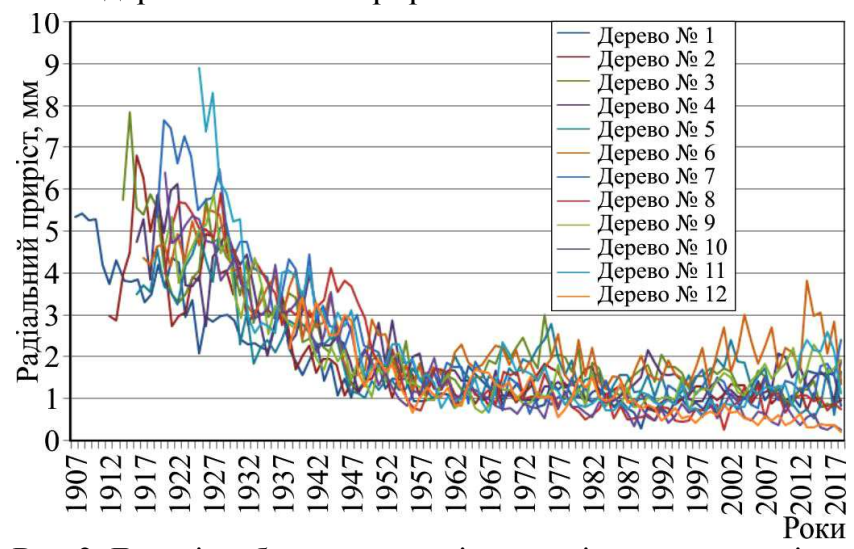

Рис. 2. Динаміка абсолютних щорічних радіальних приростів модельних дерев ялини європейської
У подальшому аналізі розрахували показники приросту кожного модельного дерева за період його онтогенезу. Розрахували також стандартні (середні квадратичні) відхилення та коефіцієнти варіації для характеристики коливань (мінливості) середніх приростів (табл. 2). Стандартне відхилення характеризує варіювання значень приросту навколо середнього приросту. Щорічні радіальні прирости модельних дерев змінюються від 0,20 (дерево № 12, 2018 р.) до 8,89 мм (дерево № 11,1925 р.). 11 із 13-ти дерев мали найменші радіальні прирости у період з 1987 по 2018 рр. 11 із 13-ти дерев мали найбільші радіальні прирости у період 3 1908 по 1929 рр.

Середні прирости модельних дерев змінюються від 1,20 (дерево № 12) до 2,50 мм (дерево № 6). Коефіцієнти варіації $(45,05-86,36 \%)$ переконливо свідчать про велику мінливість середніх приростів дерев. У дерев старших 100 років коефіцієнти варіації менші, ніж у молодших дерев, що свідчить про стабільніший приріст старших дерев.

Кожне дерево має свої, відмінні від інших дерев, особливості ходу росту. У щорічних сумарних радіальних приростах відображено вклад кожного модельного дерева у річний приріст (рис. 3). За увесь досліджуваний період найменший сумарний приріст був у 19802000 рр. Щорічні прирости показують, що домінантами в деревостані є 3 модельні дерева ялини (№ 6, 9, 11), субдомінантами - 4 дерева (№ $1,3,4,7)$, підлеглими 5 дерев (№ 2, 5, 8, 10, 12).

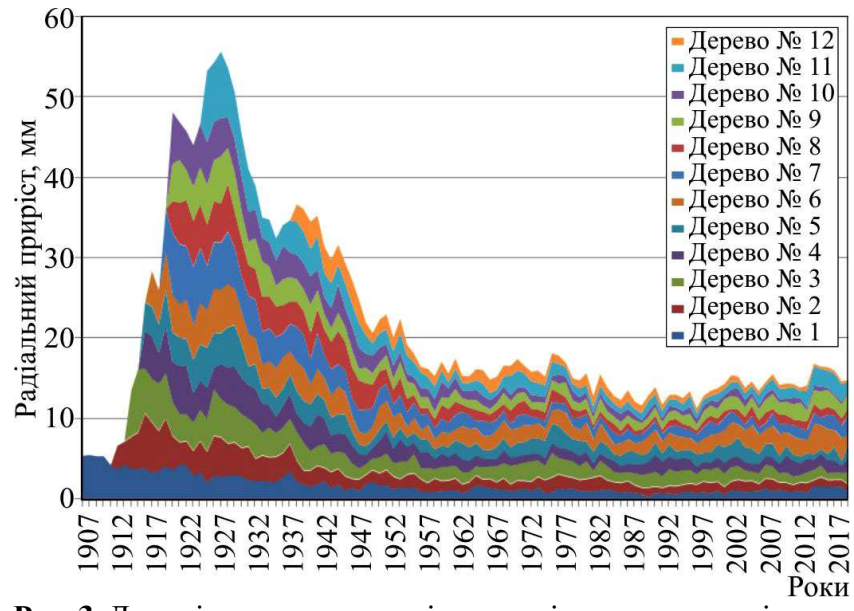

Рис. 3. Динаміка сумарних щорічних радіальних приростів модельних дерев ялини європейської

Табл. 2. Характеристика модельних дерев ялини європейської та показники радіальних приростів

\begin{tabular}{|c|c|c|c|c|c|c|c|c|c|}
\hline \multirow{3}{*}{$\begin{array}{l}\text { № де- } \\
\text { рева }\end{array}$} & \multirow{3}{*}{ Вік, років } & \multirow{3}{*}{$\begin{array}{c}\text { Діаметр, } \\
\text { см }\end{array}$} & \multicolumn{4}{|c|}{ Показники радіального приросту, мм } & \multirow{3}{*}{$\begin{array}{c}\text { Середній радіаль- } \\
\text { ний приріст дере- } \\
\text { ва, мм }\end{array}$} & \multirow{3}{*}{$\begin{array}{c}\text { Середнє квадра- } \\
\text { тичне відхилен- } \\
\text { ня, мм } \\
\end{array}$} & \multirow{3}{*}{$\begin{array}{c}\text { Коефіцієнт варіації } \\
\text { радіального прирос- } \\
\text { ту, \% }\end{array}$} \\
\hline & & & \multicolumn{2}{|c|}{ максимальний } & \multicolumn{2}{|c|}{ мінімальний } & & & \\
\hline & & & MM & рік & MM & рік & & & \\
\hline 1 & 112 & 48 & 5,41 & 1908 & 0,28 & 1989 & 1,84 & 1,199 & 65,4 \\
\hline 2 & 107 & 33 & 6,80 & 1916 & 0,71 & 1991 & 1,92 & 1,311 & 68,44 \\
\hline 3 & 105 & 42 & 7,82 & 1915 & 0,78 & 2017 & 2,31 & 1,356 & 58,60 \\
\hline 4 & 103 & 40 & 6,13 & 1922 & 0,95 & 1998 & 2,14 & 1,300 & 60,86 \\
\hline 5 & 103 & 48 & 5,17 & 1929 & 0,54 & 2014 & 1,98 & 1,053 & 53,22 \\
\hline 6 & 102 & 44 & 5,52 & 1926 & 1,07 & 1987 & 2,50 & 1,126 & 45,05 \\
\hline 7 & 100 & 38 & 7,64 & 1920 & 0,64 & 1973 & 2,30 & 1,746 & 75,79 \\
\hline 8 & 99 & 36 & 5,91 & 1928 & 0,27 & 2001 & 1,94 & 1,529 & 78,81 \\
\hline 9 & 99 & 40 & 5,89 & 1927 & 0,68 & 1966 & 1,93 & 1,226 & 63,45 \\
\hline 10 & 99 & 32 & 6,39 & 1920 & 0,26 & 2016 & 1,69 & 1,461 & 86,36 \\
\hline 11 & 94 & 36 & 8,89 & 1925 & 0,57 & 1998 & 2,04 & 1,626 & 79,75 \\
\hline 12 & 81 & 42 & 3,40 & 1940 & 0,20 & 2018 & 1,17 & 0,745 & 63,89 \\
\hline
\end{tabular}


Табл. 3. Показники середніх радіальних приростів ялини європейської за десятирічні періоди \begin{tabular}{l|l|l|l|l|l|l|l|l|l|l|l|} 
Рік & $1919-1928$ & $1929-1938$ & $1939-1948$ & $1949-1958$ & $1959-1968$ & $1969-1978$ & $1979-1988$ & $1989-1998$ & $1999-2008$ & $2009-2018$ \\
\hline
\end{tabular}

\begin{tabular}{|c|c|c|c|c|c|c|c|c|c|c|}
\hline $\begin{array}{c}\text { Радіальний } \\
\text { приріст, мм }\end{array}$ & 4,80 & 3,46 & 2,55 & 1,58 & 1,29 & 1,35 & 1,09 & 1,02 & 1,16 & 1,21 \\
\hline
\end{tabular}

Для характеристики ходу росту ялини в деревостані, дані вимірювань серій річних кілець модельних дерев усереднили за календарними роками й отримали узагальнену деревно-кільцеву хронологію (рис. 4). Щорічний приріст ялини був найбільший у першому класі віку (понад 4 мм), з часом зменшився до 1,25 мм (1958 р.) i 3 невеликими флуктуаціями був таким до 2018 р. Середній приріст деревостану за досліджуваний період 1,97 мм/рік.

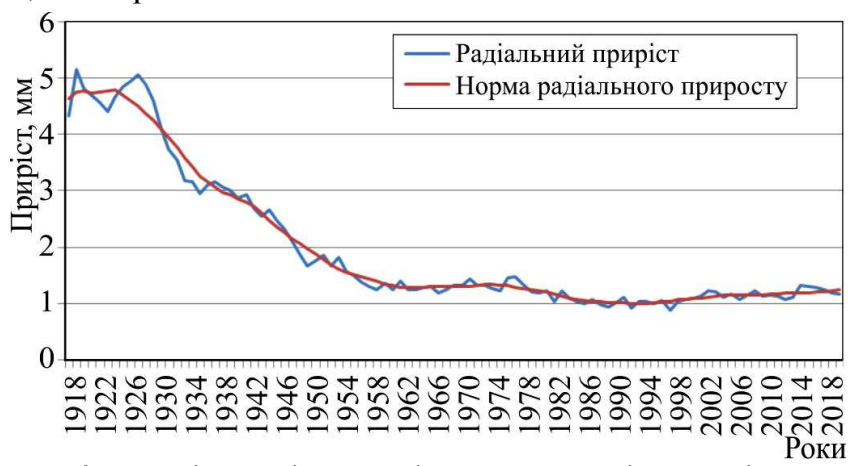

Рис. 4. Динаміка щорічних радіальних приростів та щорічних норм приростів ялини європейської

Найбільш депресивним був період з 1979 по 1998 рр., коли середній приріст модельних дерев ялини в деревостані був 1,05 мм/рік (табл. 3). За останнє десятиріччя приріст збільшився і становить в середньому 1,21 мм/рік.

Для усунення відмінностей у темпах росту дерев (унеможливлення фактора віку) і приведення даних вимірювань радіального приросту деревно-кільцевих серій до порівнюваних величин, виконали стандартизацію даних з 11-річним періодом усереднення. За тривалістю циклів і масштабами відхилень від норм наявні два типи флуктуацій: 5-6-річні сильні і 1-3-річні дрібні, які проявляються на тлі перших. Криві приростів та норм приростів (див. рис. 4) показують, що найбільш екстремальним для ялини був період, коли дерева були молодими і мали найбільші прирости, а отже, і норми приростів були найбільші. 3 віком приріст зменшувався, відхилення від норм були незначними.

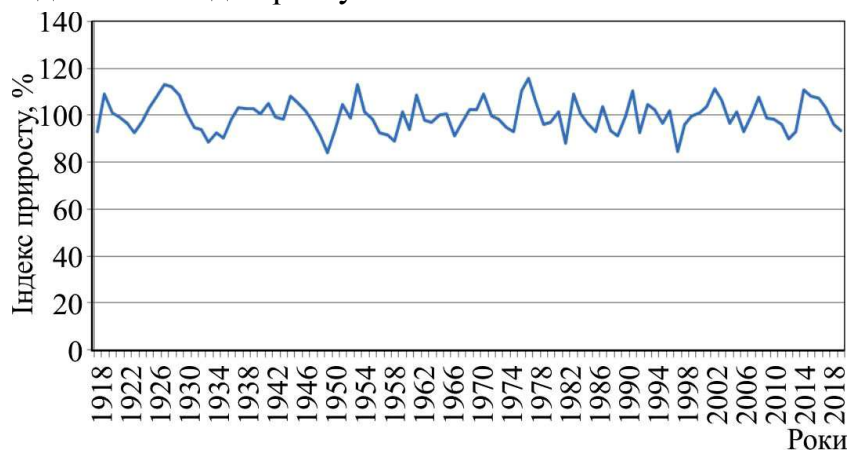

Рис. 5. Індекси щорічних радіальних приростів ялини європейської

На другому етапі стандартизації даних розрахували відносні індекси щорічних радіальних приростів (рис. 5). Індекси щорічних приростів відображають коливання приростів навколо лінії середнього $100 \%$-го приросту. Індекси приростів ялини коливаються від
84,24 до $115,52 \%$. Депресивними були $53,5 \%$ років досліджуваного періоду, коли індекси приростів були меншими $100 \%$. Середній індекс депресивних років 94,76 \%. Експресивними були 46,5 \% років досліджуваного періоду, коли індекси приростів були більшими $100 \%$. Середній індекс експресивних років - 105,34\%. За графіком індексів щорічних радіальних приростів деревостанів встановлено цикли приростів. Тривалість циклів приростів ялини становить 6-11 років, середнього циклу -8 років. У 2018 р. радіальний приріст перебував у фазі зниження приросту.

На дослідному об'єкті виконано облік природного поновлення і встановлено, що в перерахунку на 1 га кількість природного відновлення становить 21665 прим., 3 яких - 15416 прим. становить ялиця, 5833 прим. - клен-явір та 416 прим. - граб. Підрахунок підросту дав змогу встановити його теперішній склад 7Яц3Яв+Гр. Отже, триває процес зміни біоценозу.

Обговорення результатів дослідження. Здійснені дослідження спрямовані на вивчення радіального приросту ялини європейської та його динаміки в осередку всихання ялини, виявлення циклічності приростів для подальшого обгрунтування лісівничих заходів.

Дослідження показали, що кожне із модельних дерев має свої, відмінні від інших дерев, особливості ходу росту, що можна пояснити спадковою індивідуальною мінливістю, віком дерева та положенням його в деревостані (див. рис. 2, табл. 2). Середні прирости модельних дерев коливаються від 1,20 до 2,50 мм. Коефіцієнти варіації (45,05-86,36 \%) свідчать про велику мінливість середніх приростів. У дерев старших 100 років коефіцієнти варіації менші, ніж у молодших дерев, що свідчить про стабільніший приріст старших дерев. На границі між Польщею і Словаччиною в Західних Карпатах вивчали дивергенцію росту сусідніх дерев ялини європейської, тобто вираження різних тенденцій росту сусідніх дерев. Неоднорідність грунту, генетику і забруднення повітря розглядають як основні можливі механізми дивергенції росту ялини [5].

Середній радіальний приріст ялини за досліджуваний період - 1,97 мм/рік. Найбільший приріст був у першому класі віку, потім стрімко зменшився. Стрімке зниження приросту ялини (окрім всіх інших факторів, які могли вплинути на радіальний приріст), більш за все, пов'язане із загущенням деревостану та міжвидовою конкуренцією (ялини і ялиці). У Східних Карпатах за результатами інвентаризації лісів було встановлено закономірності радіального росту дерев в мішаному хвойному лісі (Picea abies i Pinus cembra). Як дискретні порушення (крупномасштабні чи дрібномасштабні), так і хронічні порушення (зміна клімату) були визначені як рушійні сили розвитку структури деревостанів [12].

Найбільш депресивним був період з 1979 по 1998 рр., коли середній приріст модельних дерев ялини в деревостані був 1,05 мм/рік (див. табл. 3). За останні двадцять років приріст дещо збільшився і становить в середньому 1,19 мм/рік. Аномально низький приріст ялини на дослідному об'єктах у 1979-1998 рр. (окрім інших факторів) може бути пов'язаний з осадженням заб- 
руднювальних речовин, які були критичними в Карпатах у ці роки. У Судетах, Західних і Східних Карпатах досліджено щодо ролі туману в осадженні шкідливих речовин та їх впливу на приріст ялини європейської. Ширину річних кілець аналізували впродовж трьох десятиліть: до інтенсивного забруднення навколишнього середовища шкідливими речовинами (1950-1960рр.), під час інтенсивного забруднення (1980-1990рр.) і після припинення забруднення (2000-2010 рр.). Дослідження показали, що найвужчі річні кільця ялини були сформовані в 1980-х роках в районах, де туман був основним джерелом осадження забруднювальних речовин [11].

За останні кілька років відбулося зниження приросту ялини, що може бути як наслідком посухи, забруднення повітря, так і інших факторів, які визначають цикли росту дерев. У 2015 р. внаслідок спекотного літа в Центральній Європі, радіальний приріст ялини європейської в Центральних Альпах в Швейцарії істотно знизився на ділянках, які розташовані нижче 1500 м H.p.M. [3].

Індекси щорічних приростів відображають коливання приростів навколо лінії середнього $100 \%$-го приросту. Виявлені дати екстремумів приросту допомагають оцінити його зв'язок з факторами середовища. Розмах коливань індексів приростів ялини становить 84,24$115,52 \%$. Починаючи із середини XX ст., частота коливання індексів приростів збільшилася і є свідченням того, що умови середовища стали більш екстремальними для росту дерев (див. рис. 5). Дослідження радіального приросту первинного лісу ялини європейської Карпатської дуги показали, що залишкова дисперсія невідомого походження є найпомітнішою дисперсією окремих карпатських ялин, але при більших просторових ієрархіях домінує кліматична дисперсія [1].

Річний приріст дерев є дискретним циклічним процесом. Для приросту дерев найхарактерніший цикли порядку 80-90 років (віковий), 30-35 років (цикл Брікнера), 22 роки (цикл Хейла або магнітний) 11 років (цикл Швабе-Вольфа або сонячний), а також цикли менших порядків: 5-6-річні, 3-4-річні, 2-3-річні. Велика частина циклічних змін росту дерев пов'язана із сонячною активністю (сукупністю фізичних явищ, що виникають на Сонці), що проявляється на Землі через зміни циркуляції атмосфери, що відповідно змінює тепловий режим і умови зволоження. Цикли приростів ялини в деревостані на дослідному об'єкті встановили за графіком індексів щорічних радіальних приростів (див. рис. 5). Тривалість циклів приросту ялини 6-11 років, середнього циклу -8 років. У 2018 р. радіальний приріст ялини перебував у фазі зниження приросту, і у наступні 4-5 років приріст ялини збільшиться на 10-15\% порівняно 32018 р. На радіальний приріст ялини в Карпатах та його цикли великий вплив мають порушення деревостанів, спричинені вітром. У Татрах (Західні Карпати, Польща) за останні 200 років виявлено 13 епізодів порушень. Вивчення історій порушень ялинових лісів дає змогу відрізнити механічні від біотичних чинників впливу на радіальний приріст [4].

\section{Висновки}

Середній радіальний приріст ялини європейської за досліджуваний період - 1,97 мм/рік. Найбільший приріст ялини був у першому класі віку, потім стрімко зменшився. Стрімке зниження приросту (окрім інших факторів) може бути пов'язане із міжвидовою конкуренцією (ялини і ялиці). Найнесприятливіші умови для росту ялини були в 1980-2000 рр., коли деревостан проходив стадію розладнання. За останні 20 років середній приріст дещо збільшився, очевидно, внаслідок розрідження деревостану. Теперішній склад підросту свідчить про те, що в майбутньому на дослідному об'єкті відбудеться зміна біоценозу.

На величину річного радіального приросту дерев впливає велика кількість як внутрішніх, так і зовнішніх комплексно діючих факторів. Тому під час виконання дендрохронологічних досліджень необхідна різнобічна інформація про природні й антропогенні фактори, які можуть впливати на радіальний приріст дерев та його мінливість. Під час дендрохронологічних досліджень в осередках всихання доцільно відбирати керни з усіх порід дерев, які формують склад деревостану, а також 3 різних за санітарним станом категорій дерев для отримання інформації про кількісні показники радіальних приростів, які передують всиханню дерев.

\section{References}

1. Bjorklund, J., Rydval, M., Schurman, J. S., Seftigen, K., Trotsiuk, V., Jandaa, P., Mikolas, M., Dusatko, M., Cada, V., Bace, R., \& Svoboda, M. (2019). Disentangling the multi-faceted growth patterns of primary Picea abies forests in the Carpathian arc. Agricultural and forest meteorology, 271, 214-224. https://doi.org/10.1016/i.agrformet.2019.03.002

2. Buras, A., Spyt, B., Janecka, K., \& Kaczka, R. (2018). Divergent growth of Norway spruce on Babia Gora Mountain in the western Carpathians. Dendrochronologia, 50, 33-43. https://doi.org/10.1016/j.dendro.2018.04.005

3. Burri, S., Haeler, E., Eugster, W., Haeni, M., Etzold, S., Walthert, L., Braun, S., \& Zweifel, R. (2019). How did Swiss forest trees respond to the hot summer 2015?. Erde, 150(4), 214-229. https://doi.org/10.12854/erde-2019-420

4. Holeksa, J., Zielonka, T., Zywiec, M., \& Fleischer, P. (2016). Identifying the disturbance history over a large area of larch-spruce mountain forest in Central Europe. Forest ecology and management, 361, 318-327. https://doi.org/10.1016/i.foreco.2015.11.031

5. Holubchak, O., Korol, S., Melnychuk, I., \& Prykhodko, M., (2019). Optimization of forest ecosystem recreational services formation in conditions of decentralization in Ukraine. Advances in Economics, Business and Management Research: 2019 7th International Conference on Modeling, Development and Strategic Management of Economic System (MDSMES 2019). Ivano-Frankivsk, Ukraine, pp. 227-231. https://doi.org/10.2991/mdsmes19.2019 .43

6. Koval, I. M. (2006). Dendrochronology in Ukraine: Retrospectives and Prospects for Development. Forestry, forestry, paper and wood industry. Interagency Scientific and Technical Collection, 31, 221-227. [In Ukrainian].

7. Koval, I. M. (2006). Dendrokhronolohiia v Ukraini: retrospektyva i perspektyvy rozvytku. Forestry, forestry, paper and woodworking industries, 31, 221-227. [In Ukrainian].

8. Lovelius, N. V., \& Grican, Ju. I. (1998). Forest ecosystems of Ukraine and heat and moisture supply. Neva, Saint Petersburg. [In Russian].

9. Lovelius, N. V., \& Gritcan, Iu. I. (1998). Lesnye ekosistemy Ukrainy i teplovlagoobespechennost. St. Petersburg: Neva, 335 p. [In Russian].

10. Makarenko, C. C. (2018). Assessment of forestry activity of Ukraine in the context of time requirements. Economy and society, 19, 472-483. [In Ukrainian].

11. Makarenko, C. C. (2018). Otsinka diialnosti lisovoho hospodarstva Ukrainy u konteksti vymoh chasu. Economy and society, 19, 472-483. [In Ukrainian]. 
12. Matjushevskaja, E. V. (2017). Variability factors for radial tree growth. Belarusian State University, Minsk. [In Russian].

13. Matiushevskaia, E. V. (2017). Faktory izmenchivosti radialnogo prirosta derevev. (Kiseleva, V. N. Scientific Ed.). Minsk: BGU, 231 p. [In Russian].

14. Matskovsky, V. (2016). Climatic signal in tree-ring width chronologies of conifers in European Russia. International journal of climatology, 36(9), 3398-3406. https://doi.org/10.1002/joc.4563

15. Myskow, E., Blas, M., Sobik, M., Godek, M., \& Owczarek, P. (2019). The effect of pollutant fog deposition on the wood anatomy of subalpine Norway spruce. European journal of forest research, 138(2), 187-201. https://doi.org/10.1007/s10342-01801160-4

16. Popa, I., Nechita, C., \& Hofgaard, A. (2017). Stand structure, recruitment and growth dynamics in mixed subalpine spruce and Swiss stone pine forests in the Eastern Carpathians. Science of the total environment, 598, 1050-1057. https://doi.org/10.1016/..scitotenv.2017.04.169

17. Prykhodko, M., Havadzyn, N., Horal, L., Melnychuk, I., \& Berlous, M. (2019). Ecosystem Services in the Management System of Ecological Safety of Territorial Units. Advances in Economics, Business and Management Research: 2019 7th International Conference on Modeling, Development and Strategic Management of Economic System (MDSMES 2019). Ivano-Frankivsk, Ukraine, 90-95. https://doi.org/10.2991/mdsmes-19.2019.18

18. Schurman, J. S., Babst, F., Bjrklund, J., Rydval, M., Bace, R., Cada, V., Janda, P., Mikolas, M., Saulnier, M., Trotsiuk, V., \& Svoboda, M. (2019). The climatic drivers of primary Picea forest growth along the Carpathian arc are changing under rising tempe- ratures. Global change biology, 25(9), 3136-3150. https://doi.org/10.1111/gcb.14721

19. Sedmakova, D., Sedmak, R., Bosela, M., Jezik, M., Blazenec, M., Hlasny, T., \& Marusak, R. (2019). Growth-climate responses indicate shifts in the competitive ability of European beech and Norway spruce under recent climate warming in East-Central Europe. Dendrochronologia, $\quad 54, \quad 37-48$. https://doi.org/10.1016/j.dendro.2019.02.001

20. Shijatov, S. G., Vaganov, E. A., Kirdjanov, A. V., Kruglov, V. B., Mazepa, V. S., Naurzbaev, M. M., \& Hantemirov, R. M. (2000). Methods of dendrochronology. Part 1. The basics of dendrochronology. Collection and receipt of tree-ring information. Krasnoyarsk State University, Krasnoyarsk. [In Russian].

21. Shiiatov, S. G., Vaganov, E. A., Kirdianov, A. V., Kruglov, V. B., Mazepa, V. S, Naurzbaev, M. M., \& KHantemirov, R. M. (2000). Dendrochronology methods. Part I. Fundamentals of dendrochronology. Collection and receipt of tree-ring information. Study guide. Krasnoyarsk: KrasSU, 80 p. [In Russian].

22. Shvedov, F. N. (1892). Tree like a drought record. Meteorological Bulletin, 5, 163-178. [In Russian].

23. Shvedov, F. N. (1892). The tree is like a chronicle of drought. Meteorological Bulletin, 5, 163-178. [In Ukrainian].

24. Svobodova, K., Langbehn, T., Bjorklund, J., Rydval, M., Trotsiuk, V., Morrissey, R. C., Cada, V., Janda, P., Begovic, K., \& AghLabusova, J. (2019). Increased sensitivity to drought across successional stages in natural Norway spruce (Picea abies (L.) Karst.) forests of the Calimani Mountains, Romania. Trees-structure and function, 33(5), 1345-1359. https://doi.org/10.1007/s00468-019$\underline{01862-1}$

N. F. Prykhodko', T. V. Parpan', O. M. Tkachuk1, M. M. Prykhodko²

${ }^{1}$ P. S. Pasternak Research Institute for Mountain Forestry, Ivano-Frankivsk, Ukraine ${ }^{2}$ Ivano-Frankivsk National Technical University of Oil and Gas, Ivano-Frankivsk, Ukraine

\section{RADIAL GROWTH OF EUROPEAN SPRUCE (PICEA ABIES L.) IN ITS DRYING OUT ENVIRONMENT (GORGANY, THE UKRAINIAN CARPATHIANS)}

In recent years, there has been an intensive drying of spruce forests in the Ukrainian Carpathians. This process causes economic damage, and leads to deterioration in the living conditions of spruce forests, and also reducing their ecosystem services. In order to define the dynamics of the radial growth of European spruce, as well as further justification of forestry measures, dendrochronological studies were conducted in the Gorgany Massif in a mixed forest stand with a very weakened sanitary state and complex structure in 2019. The analysis of the width of tree rings from the selected core samples of spruce trees was performed. Based on it, in the 100year-old (1918-2018) absolute individual radial increment values were obtained by individual, generalized dendrochronology, as well as their indices. A sharp decrease in the growth of spruce was revealed starting from the first age class, which may be associated (among other factors) with interspecies competition (spruce and fir). The average growth of the stand for the study period is $1.97 \mathrm{~mm} /$ year. Even less radial growths of spruce (on average $1.05 \mathrm{~mm} /$ year) were recorded during the period from 1980 to 2000 , which is explained by the presence of the stand at the disorder stage. Over the past 20 years, the average growth has increased slightly $(1.19 \mathrm{~mm} / \mathrm{year})$, apparently due to rarefaction of the stand to a fullness of 0.66 . Fluctuations in relative growth indices are in the range of $84.24-115.52 \%$.The average duration of growth of cycles is 8 years. Since the middle of the last century, the frequency of growth fluctuations has increased and indicates that the environmental conditions for spruce growth have not become very favourable. In the future, a change in the biocenosis will take place at the experimental facility. Thus, the current composition of the undergrowth indicates the upcoming change in the composition of the stand. When conducting dendrochronological studies in places of drying of spruce, comprehensive information is needed on natural and anthropogenic factors that can affect the radial growth of trees and its variability.

Keywords: individual tree-ring chronologies; generalized tree-ring chronologies; radial growth indices; cycles of radial growth. 